\title{
Learning for a Sustainable Economy: Teaching of Green Competencies in the University
}

\section{Ma Ángeles Murga-Menoyo}

Unesco Chair of Environmental Education and Sustainable Development, Universidad Nacional de Educación a Distancia (UNED), 28040 Madrid, Spain; E-Mail: mmurga@edu.uned.es;

Tel.: +34-91-398-88-32

Received: 31 January 2014; in revised form: 6 May 2014 / Accepted: 9 May 2014 /

Published: 15 May 2014

\begin{abstract}
This paper looks at universities as training centers for a sustainable economy. Their remit is to promote the required competencies to achieve that aim, including competencies in sustainability. This article describes the role that the universities in Spain are fulfilling with respect to these issues and presents a training proposal that comprises four key competencies in sustainability with their corresponding performance indicators that permit the evaluation of different levels of achievement in training processes. These competencies must embrace their formative role not only with regard to future graduates who will be employed in "green jobs" per se, but also with regard to those alumni who will work in all the other productive sectors, in addition to all citizens directly and indirectly involved in the wider economy as consumers, producers and (direct or indirect) recipients of its effects. The proposal is based on the recommendations of the Conferencia de Rectores de Universidades Españolas (CRUE: Conference of Chancellors of Spanish Universities), and can be adapted to the teaching programs of different subjects in order to facilitate the training necessary in general competencies of sustainability within the ambit of the subjects taught. Furthermore, this proposal follows the institutional strategy of CRUE to promote curricula sustainability through the inclusion of the principles and values of sustainable development in every degree and educational program taught. This proposal could also be applied to other cultural contexts with similar characteristics.
\end{abstract}

Keywords: sustainable economy; education for sustainable development; competencies in sustainability; green competencies; curricular sustainability; higher education; learning; green economy; Spain 


\section{Introduction}

In the context of sustainable development and poverty eradication, for many years but with greater emphasis after the celebration of the Summit Rio+20 [1], the economy has become one of the great challenges; it is a fundamental pillar for the construction of the new sociocultural model. A sustainable economy is needed, which is viable in the long term and responds both to the needs of preservation of the natural environment and to social fairness. From this approach, the opportunities offered by the green economy allow advancements in the direction described.

In Western countries, which are currently undergoing a deep economic crisis, this new model presents itself as a promising mean to stimulate productive activity and employment [2,3]. There are discussions about a transition to a sustainability economy, in which the framework of the green economy, together with the protection and efficient use of the natural resources, can act as a driving force of social progress and elevation of living standards for the inhabitants of the planet [4-6]. The objective is a growth that emphasizes the social dimension of the economy, at the service of the common good. This has been denoted as "green growth" [7-9].

This transformation towards a sustainability economy involves changes, some of them very deep, in the structures of employment and in the professional profiles of the workers [10]. The creation/destruction of employment will have as a consequence an increase in worker's mobility both between and within sectors, and new qualification needs for the professionals and workers will appear, which will greatly influence the education sector. These changes will also require a generalized sensitivity, of the professionals and of the entire population, coherent with the principles and values of sustainable development.

A change of model of this magnitude requires multiple mechanisms and strategies. Among them, education plays an important role. It has a mission in the framework of educating professionals and also in the context of the education throughout life and citizenship education.

This article is focused on describing the role that the university in Spain is fulfilling with respect to these issues and presents a proposal for the teaching of competencies in sustainability, which is based on the recommendations of the Conferencia de Rectores de Universidades Españolas (CRUE: Conference of Chancellors of Spanish Universities). The paper is organized as follows: Section 2 describes the concepts of green economy and sustainable economy, according to the definitions used in the competence model considered. It also presents the different types of competencies to be taught in higher education and, specifically, it explains the concept of competencies in sustainability. Section 3 includes a few brief references to the context of the proposal: the theoretical framework-Agenda 21 - and the strategies deployed by Spanish universities in the direction of sustainable development. These strategies are grouped in two development lines: environmentally efficient institutional management and curricular sustainability. Section 4 focuses on the process of curricular sustainability and clarifies the competencies in sustainability in the context of higher education in Spain. A proposal of key competencies in sustainability, with their corresponding performance indicators in different levels of achievement, is presented in Section 5, while Section 6 concludes the paper. 


\section{Key Competencies for a Sustainability Economy}

In this work, we differentiate between two concepts with very different meanings: sustainable economy and green economy. This distinction is important for the model proposed in Section 5 and, for this reason, the current section focuses on explaining the two concepts that, in this paper, are never used as synonyms.

The "Declaration on Green Growth" adopted by the OECD affirms that "in order for countries to advance the move towards sustainable low-carbon economies, international co-operation will be crucial in areas such as the development and diffusion of clean technologies, for example carbon capture and storage, renewable energy technologies, and application of green ICT for raising energy efficiency, and the development of an international market for environmental goods and services" [9] (p. 1). In this context, "the efforts to improve resource efficiency and de-carbonize our energy supply and production systems has given rise to the term 'green economy', and a new suite of terms such as 'low-carbon economy', 'green jobs', 'eco-literacy' and 'green skills"' [11] (p. 16). This is the definition of the term "green economy" used in this paper, while other authors define it as an economy that results in "improved human well-being and social equity, while significantly reducing environmental risks and ecological scarcities" [2] (p. 16).

The concept of "sustainable economy" entails a broader area. It is used in reference to the sustainable development of the economic dimension of society, and includes industrial processes, financial relationships, employment structure and consumption patterns [3,5]. This means that green economy is a subset of a sustainable economy; it contributes to a sustainable economy but, on its own, it is not enough to achieve it.

Both in a green economy and in a sustainable economy, individuals will need to have basic (general) competencies in sustainability. Additionally, in the case of green economy, competencies of a technical profile are required in order to perform the green jobs.

The existence of a qualified workforce, which possesses the required professional education, is a prerequisite for a green economy. For this reason, it is necessary to direct formative efforts towards training in specialized technical skills expressly sought after by this job market; this issue is particularly relevant for the STEM (science, technology, engineering, and mathematics) disciplines [2] (p. 572).

However, the green economy is not only concerned with eco-activities or those jobs considered "green." Promoting efficiency in the use of natural resources and fossil fuels, as well as the decrease in polluting emissions or waste, brings about a pattern of production-consumption that has potential effects on every sector of the productive activity. The more traditional sectors, owing to this "green" tendency, feel encouraged to adapt to the new conditions and circumstances in the market, dictated by the requests of competitiveness. A transformation across all sectors is, therefore, initiated via "green growth" and, in that sense, it can be stated that such a transformation affects all professions more or less intensively [12].

The above interpretation can be made because, on the one hand, the transition towards a sustainable economy anticipates an increase in jobs in the green economy sector; for instance, those jobs related to waste collection and recycling, renewable energies, or the management of natural spaces demand professionals who are equipped with specialized competencies to perform such tasks. On the other hand, this transition will imply that professionals currently holding traditional jobs will need to update 
themselves to acquire the new competencies necessary in the context of sustainable development. It should also not be overlooked that the overall population - potential recipients of green products and production processes - likewise need to possess competencies in sustainability to be able to value the advantages offered by the new economic model. The latter competencies, indispensable for any citizen belonging to a sustainable society, could be even more relevant than those more specialized technical competencies (green skills) distinctive of a particular productive sector, because, by leading to changes in mentality, they modify the social patterns and lifestyles, hence favoring the change in the production-consumption economic model and providing the necessary conditions for the development of the green economy.

There are four types of key competencies for a sustainable society. The first type corresponds to the traditional general competencies - of instrumental, interpersonal or systemic profiles - that can be applied to the situations of everyday life. The second type contains those competencies required for the social behaviors and styles that reinforce a sustainable economy. The third type are the competencies that make the performance of the green jobs technically possible, and are specific of each productive sector of the green economy, while the fourth type contains those that derive from the processes of continuous education for updating professionals. All four of them are part of the required knowledge that the citizens should have in order to achieve the future viability of our societies.

Figure 1. Competencies and skills needs for a sustainable economy. Based on CEDEFOP [13].

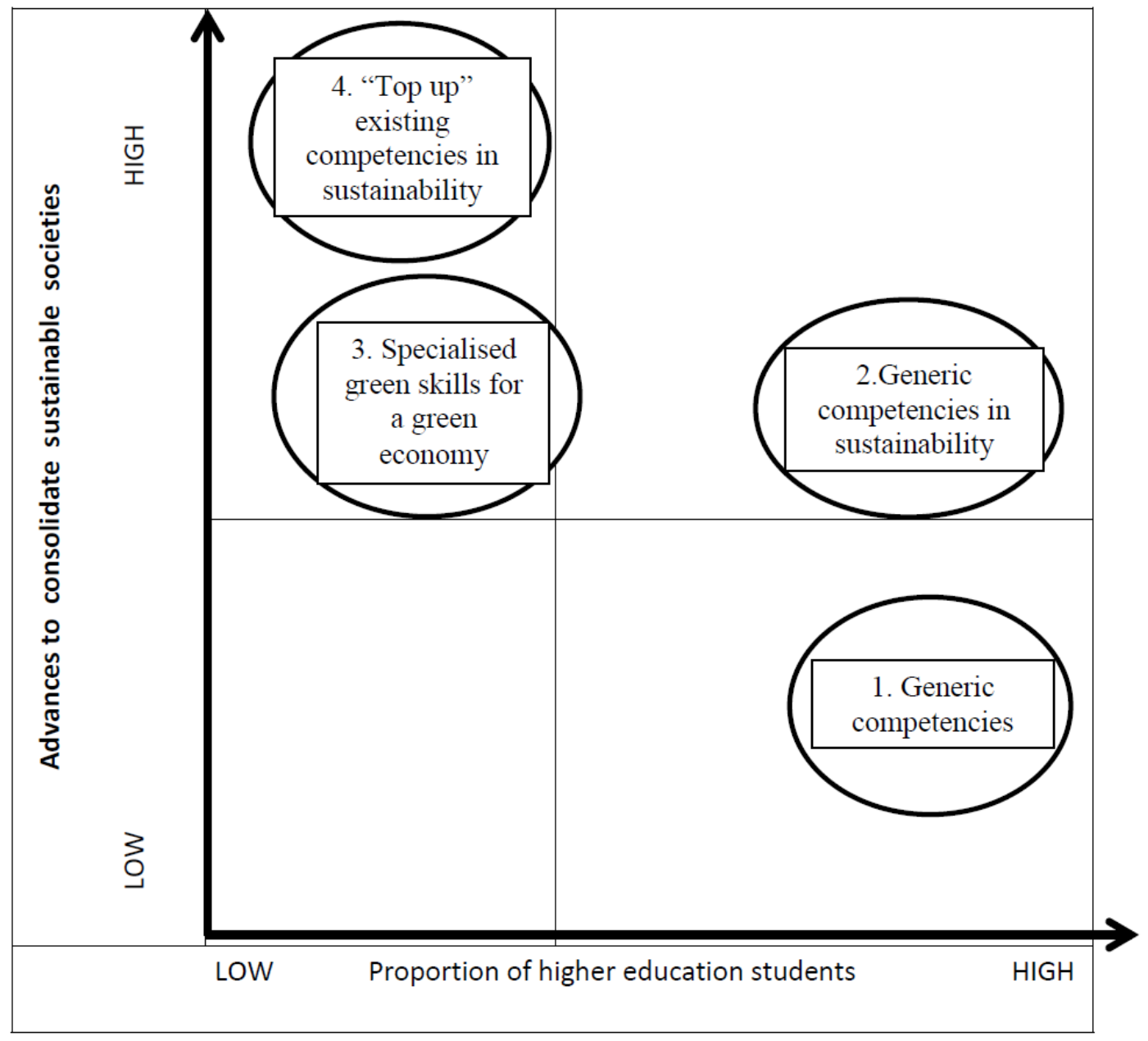


The four types of competences are depicted in Figure 1, which shows in the vertical axis the progress from a traditional society to a society characterized by sustainability in its development. From this point of view, the generic competencies are on a first level of advancement, and they are the basis for the other three types. On top of them are the generic competencies in sustainability, which are equally necessary for every citizen. A third level contains the specialized green skills, which are of a technical profile and not applied to the whole population. Finally, a level to "top up" existing competencies in sustainability is required for a dynamizing leadership in social processes of sustainable development. The horizontal axis in Figure 1 shows the degree of specialization of the different types of competencies and, consequently, the amount of presence they need to have among the university students. Both the generic competencies and the generic competencies in sustainability should be acquired by the totality of the students. The specialized green skills and the "top up" of existing competencies in sustainability, however, are reserved for graduates of certain specific programs.

Societies rely on education - at its various levels and modalities — as an indispensable instrument to encourage the acquisition of said competencies by its citizens. The first issue that arises in that respect, prior to any other pedagogical consideration, is determining the exact key competencies that learning processes will have to teach in each of the aforementioned categories; secondly, it will be necessary to define such competencies in an operational manner; and, thirdly, decide which centers or teaching institutions should be responsible for providing the required academic training to achieve them. All the above are questions that have been extensively and increasingly discussed in recent years [14-39].

With regard to the first issue above, the main difficulty apparently emerges when establishing and defining the general competencies in sustainability. Indeed UNESCO, in the resolution adopted on the report of Commission III at the 20th plenary meeting in 2003 [14] (p. 35), indicates an appropriate path to take by pointing to the "Earth Charter" as a fundamental framework of general reference in any training process towards sustainable development; there are a great deal of "good practice" cases to date that have followed its guidelines [15-22]. However, an international consensus on what the general key competencies in sustainability should precisely be does not yet seem to have been reached, as is reflected in the ample existing literature ([23-36]; among others).

Nevertheless, it is important to note that the group of experts tasked by UNESCO to track the evolution of The United Nations Decade of Education for Sustainable Development (DESD), 2005-2014, has identified that certain key processes underpin the education for sustainable development (ESD) frameworks and practices [37] (p. 104). These include: processes of collaboration and dialogue (including multi-stakeholder and intercultural dialogue); processes which engage the "whole system"; processes which innovate curriculum as well as teaching and learning experiences; and, processes of active and participatory learning. The group of experts also highlights that learning for ESD refers to all those engaged in ESD, including learners, facilitators, coordinators as well as funders. Their report also concludes that often learning is interpreted as the gaining of knowledge, values and theories related to sustainable development but that ESD learning also refers to: learning to ask critical questions; learning to clarify one's own values; learning to envision more positive and sustainable futures; learning to think systemically; learning to respond through applied learning; and, learning to explore the dialectic between tradition and innovation.

The call of the DESD was directed at all the education centers, including the higher education centers. It was stated that universities should have among their goals an offer of educational programs 
that are useful in the challenge of sustainability. Universities have been working in that direction for more than two decades. The celebration in Talloires (France) in 1990 of the 1st Conference of the Association of University Leaders for a Sustainable Future (ULSF) signaled already in the nineties the symbolic starting date of a concerted process of international university network building, joined together in a serious commitment to promote social change toward sustainability. Subsequently, in 2000, a global network was born, the Global Higher Education for Sustainability Partnership (GHESP). It originally consisted of four members, one being UNESCO, but presently more than a thousand higher education institutions belong to this partnership. The reference framework for all those institutions is Agenda 21 [38], a document that is a result of the first Earth Summit celebrated in Rio de Janeiro (Brazil).

\section{Reference Framework}

This section introduces the context for the proposal presented in the following sections. It includes a brief presentation of the theoretical framework, Agenda 21, and the strategies deployed by Spanish universities in the direction of sustainable development. These strategies are grouped in two development lines: environmentally efficient institutional management, and curricular sustainability. The first line is achieved through the creation of an increasing number of green campuses, characterized by having facilities, buildings and activities that are managed using sustainability criteria and that are efficient in the use of energy, resources and waste recycling. The second line is achieved by including the principles and values of sustainable development in every degree and educational program taught at the higher education centers (this is not a mandate but a recommendation of CRUE, and an increasing number of universities are implementing it).

Agenda 21, in its Article 36 entitled "Promoting Education, Public Awareness and Training [38]," points precisely to the importance of education as a tool to equip citizens with the knowledge, attitudes, values and skills necessary for sustainable development. Ultimately, it refers to the concept of "competence" in the sense that is generally accepted today in the educational sphere.

The text is directed to countries, institutions, and national and international organizations, entrusting them to take action with respect to three central areas:

(a). Reorienting education towards sustainable development, aim for which "environment and development education should deal with the dynamics of both the physical/biological and socio-economic environment and human (which may include spiritual) development, should be integrated in all disciplines, and should employ formal and non-formal methods and effective means of communication" [38] (art. 36.3).

(b). Increasing public awareness, as an essential element in a world campaign for education with a view to reinforcing attitudes, values and measures compatible with sustainable development, and prioritizing responsibility and local control over activities in this area.

(c). Promoting training, that is, giving preference to the acquisition of knowledge related to employability and to participation in activities related to environment and development issues, whilst encouraging a greater awareness of issues in connection with those themes. 
In the twenty years since the writing of Agenda 21, the universities have contributed to the education for sustainable development following its directives with different strategies and initiatives. Among them are the following: the creation of programs specialized on the problematic of sustainable development, the education and training of social leaders and highly qualified experts in order to tackle such a problematic, an improvement of the institutional environmental management and promotion of green campuses, and the construction of technological campuses for a green economy. Moreover, they have simultaneously reinforced ties, strengthening mutual collaboration.

Among the network of higher education centers working towards sustainability, two in particular should be mentioned, both promoted by international organizations, one worldwide and one European. The first is the University Leaders for a Sustainable Future (USLF), known as the Talloires Network, with its head office in Washington, and built around the eponymous declaration; and the second is the Copernicus-Campus University Network for Sustainability, under the auspices of the Conference of Rectors of Europe, embryo of the present Association of European Universities, whose principles are summarized in the "Letter to Universities Supporting Sustainable Development (Copernicus Chapter)" [39], subscribed to by several hundreds of European universities.

In the particular case of Spain, which is the framework in which the model proposed in this paper is in process of being tested and implemented, among the universities that are at the forefront, and count on a consolidated Agenda 21, are: the Autonomous University of Madrid, with the ECOCAMPUS project [40]; Valencia University, with Project Campus Sostenible-UVEG [41]; and the Autonomous Universities of Barcelona and Girona, which are members of the ACES network of Catalan universities [42], committed for many years to elaboration of a theoretical model for the curricular sustainability in higher education, and the EDUSOST network [43], devoted to research on education towards sustainability. In addition, among those which have promoted specialized postgraduate studies there is UNED, offering a Master's degree course in Environmental Education and Sustainable Development, which started in the early ' 90 s and is groundbreaking in this field, being an initiative of the UNESCO Chair in Environmental Education and Sustainable Development [44], based at that university.

Moreover, all the universities in Spain are integrated into the CRUE, under which umbrella the "Comisión sobre Calidad Ambiental y Desarrollo Sostenible" (CADEP: Commission on Environmental Quality and Sustainable Development) [45] was created in 2002. CADEP has the following goals: to boost curricular sustainability in university studies, to encourage better practice in the environmental management of universities, to make the university community aware of the principles of sustainability, and to participate actively in social initiatives that contribute to improve environmental quality and sustainable development in society. The aforementioned commission relies on a specific working group to study the difficulties of curricular sustainability, a process that consists of the introduction of principles and values of sustainable development into teaching projects at university centers. The objective is to encourage that training processes in university classrooms overall lead to training students in general competencies in sustainability. Experts from more than a dozen universities take part in this working group; one of the principal research areas focuses on identifying the key competencies for sustainability, as well as the training processes and methodologies that favor their acquisition. 


\section{Competencies in Sustainability in the Context of Higher Education in Spain}

Since the Lisbon European Council [46] announced the need to direct training processes towards the acquisition of competencies, attempts to clarify and define competencies in sustainability in an operative manner, and to identify its components, have gradually multiplied.

At higher education levels, universities have responded to the challenge with a greater emphasis possibly after the Europe 2020 proposal, one of whose three declared priorities is the "sustainable growth: promoting a more resource efficient, greener and more competitive economy" [47] (p. 3). This is undoubtedly the case, after the resolution adopted by the Conference on Sustainable Development "Río+20," in its final declaration titled The future we want, which considers the green economy as an important instrument towards fomenting sustainable development, emphasizes that "we note the importance of ensuring that workers are equipped with the necessary skills, including through education and capacity-building, and are provided with the necessary social and health protections" [1] (p. 11).

At our universities, it seems appropriate to highlight three different lines of work whose focus is the systematic training of competencies for sustainability:

(a). Diagnoses of the situation based on evaluative research carried out regarding the presence of competencies in sustainability in university degrees (and constructing the instruments to achieve that end (questionnaires, templates with categories for analysis, etc., [48-52]; among others).

(b). Methodological innovations in the training processes, to reinforce the acquisition of general competencies in sustainability by students ([53-58]; among others).

(c). Teacher training, both initially and continuously, in the necessary competencies to lead training processes within the framework of education in sustainable development ([59-64]; among others).

These lines of work have become consolidated as a result of the support provided by CRUE via CADEP, the aforementioned sectorial commission. Following a suggestion by the expert group devoted to the study of curricular sustainability, CADEP recommended to CRUE university members the introduction of four generic competencies in sustainability (named $\mathrm{SOS}_{1}, \mathrm{SOS}_{2}, \mathrm{SOS}_{3}$ and $\mathrm{SOS}_{4}$ ) listed in Table 1 in their university degrees and training programs.

Table 1. Training challenges for a Sustainable Economy in Higher Education [65].

\begin{tabular}{ll}
\hline & \multicolumn{1}{c}{ Generic competencies in sustainability } \\
\hline $\mathrm{SOS}_{1}$ & $\begin{array}{l}\text { Critical contextualization of knowledge, establishing inter-relationships between social, economic and } \\
\text { environmental problems, local and/or global }\end{array}$ \\
\hline $\mathrm{SOS}_{2}$ & Sustainable use of resources and prevention of negative impacts on the natural and social environment \\
\hline $\mathrm{SOS}_{3}$ & Participation in community processes which promote sustainability \\
\hline $\mathrm{SOS}_{4}$ & Application of ethical principles related to sustainability values in personal and professional behavior \\
\hline
\end{tabular}

In order to correctly perform these competencies in sustainability, there is an a priori requirement of possessing the generic traditional competencies in knowledge, values, attitudes and skills, which are part of a university-level education. Table 2 presents these competencies classified into three large categories: instrumental, interpersonal and systemic, following the proposal of the Tuning Project, endorsed by the European Commission [66]. The systematization is fully in harmony with the proposal of key competencies promoted by the DeSeCo project [67] for the school system; these competencies 
are characteristic of both a basic education for all the population, and of the foundation of traditional competencies belonging to higher education.

Table 2. Generic traditional competencies at university level. Source: Based on the Tuning Project [66].

\begin{tabular}{|c|c|c|}
\hline \multicolumn{3}{|c|}{ GENERIC TRADITIONAL COMPETENCIES } \\
\hline \multirow{4}{*}{ INSTRUMENTAL } & $\begin{array}{l}\text { Cognitional } \\
\text { competencies }\end{array}$ & $\begin{array}{l}\text { Capacity to understand } \\
\text { Manipulate ideas and thoughts }\end{array}$ \\
\hline & Methodological skills & $\begin{array}{l}\text { Time management } \\
\text { Learning strategies } \\
\text { Decision making } \\
\text { Problem solving }\end{array}$ \\
\hline & Technological skills & $\begin{array}{l}\text { Use of machinery } \\
\text { Computer skills } \\
\text { Information management }\end{array}$ \\
\hline & $\begin{array}{l}\text { Linguistic } \\
\text { skills }\end{array}$ & $\begin{array}{l}\text { Spoken and written } \\
\text { communication } \\
\text { Second language }\end{array}$ \\
\hline \multirow{2}{*}{$\begin{array}{l}\text { INTERPERSONAL } \\
\text { (favoring social interaction and } \\
\text { cooperation) }\end{array}$} & Individual capacities & $\begin{array}{l}\text { Capacity to express own feelings } \\
\text { Critical and self-critical skills }\end{array}$ \\
\hline & Social capacities & $\begin{array}{l}\text { Capacity to work in a team } \\
\text { Capacity to express a social or } \\
\text { ethical commitment }\end{array}$ \\
\hline $\begin{array}{l}\text { SYSTEMIC } \\
\text { (skills and capacities } \\
\text { concerning systems as a } \\
\text { holistic approach) }\end{array}$ & \multicolumn{2}{|c|}{$\begin{array}{l}\text { Combining understanding, sensibility and knowledge } \\
\text { Requiring instrumental and interpersonal competencies as } \\
\text { a base }\end{array}$} \\
\hline
\end{tabular}

The above competencies, both the generic traditional competencies, and the generic competencies in sustainability, are key for the transformation of graduates into agents of sustainable development in the different dimensions that it entails, amongst which is that of economic competency, which relies on the green economy as a prominent instrument of change towards a sustainable economy.

\section{Proposal for the Teaching of Generic Competencies in Sustainability at the University}

Taking into consideration the two typologies of competencies analyzed in the previous section (generic traditional competencies and generic competencies in sustainability), we defend the integration of both in a single model of competencies for higher education, to be applied at all the degrees and for all the students. The teaching projects would have in this model their starting point for the planning and design of the teaching-learning processes. After this starting point, the teaching projects would have to include, when applicable, the other types of competencies, which are specific to each specialty or degree. The proposal of this paper is focused $\mathrm{i}=$ on a teaching-learning process for teaching competencies in sustainability. It presents a rubric designed for the evaluation of the learning progress, with achievement indicators and different performance levels. This model has been derived from the wide experience in projects for teaching innovation, for which the UNESCO Chair of 
Environmental Education and Sustainable Development of the UNED has used different training methodologies in the subjects taught [55,56,68-70].

As shown in Figure 2, the generic key competencies in sustainability are obtained starting from an epistemological and axiological matrix. The epistemological principles of the model are the characteristic principles of the complex thinking, which comprises a holistic and systemic vision of the world [71-76]. The Earth Charter reflects the axiological principles, which are coherent with the ethics of justice, but also with the ethics of care [77]. Among the epistemological principles, the systemic, hologramatical, dialogical, organizational recursivity, retroactivity and self-eco-organization principles are the most prominent, and they in turn are complemented by the values of respect and care about the community of life, ecological integrity, social and economic justice, democracy, non-violence and peace.

Figure 2. Base and dimensions of the competencies in sustainability.

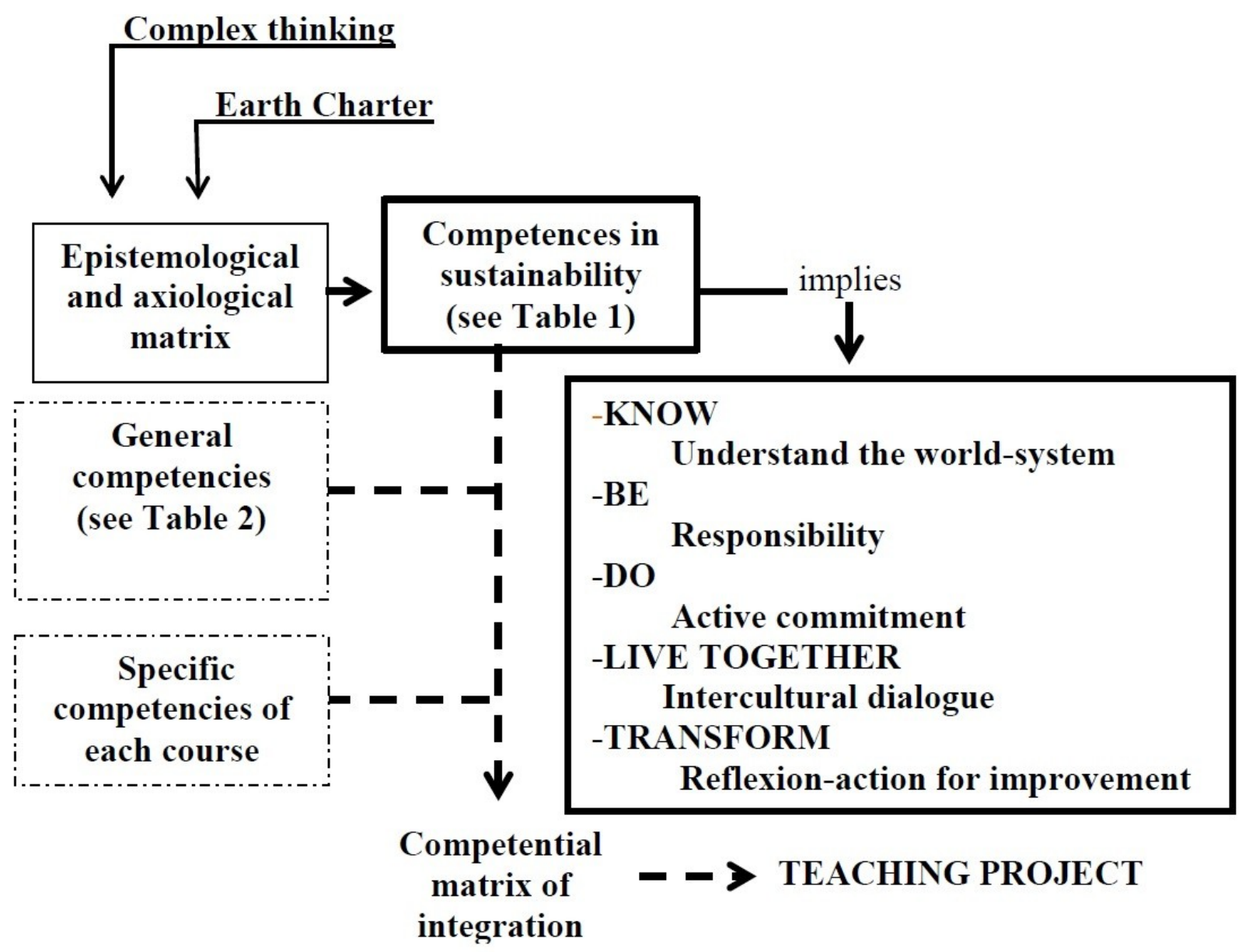

The principles and pillar values of this educational model have in the concept of interdependency their cornerstone, both from the intellectual and from the emotional perspectives. First, the model aims at capacitating the students to understand the world-system, which is formed by a network of interrelations and reciprocal interdependencies between the multiple factors implicated in the social phenomena, and between the elements that result in the life in its extraordinary diversity. Second, the model also has the objective to develop a dense axiological network in the framework of the ethics of care, inspired not as much in the enlightened reasoning as in the humanitarian sensitivity and emotional intelligence. The ethic base of this educational model has its fundamental identity in the 
universal responsibility, differentiated (higher among the most gifted), synchronous and diachronic (with the species).

The competencies in sustainability have a transversal curricular profile. Additionally, all of them contribute to consolidate the big pillars of education: learning to know, learning to be, learning to do and learning to live together [78]. In each of them, the focus is in those issues that are more relevant from the perspective of sustainable development: holistic understanding of the world-system (to know), the responsibility (to be), the active commitment (to do) and the intercultural dialogue (to live together).

Additionally, it is important to highlight the transforming capability of the competencies in sustainability. The proposed model encourages a new way of understanding and sensing the world; namely, a different manner of interrelating with human beings, and with the other living beings that inhabit the planet, and with nature itself. Moreover, because of the meaning attributed to the concept of responsibility, it is consistent with the demands of sustainable development. It admits that the responsibility of current human beings is not only synchronous but also diachronic; i.e., with the people that might inhabit the planet in the future. Besides, it accepts that it is a differentiated responsibility; in each current human being it is proportional to his/her circumstances and strengths, among which are social and economic position and intellectual capacity.

From a methodological point of view, the training in competencies that the model assumes as its own requires procedures focused on the student, who is the main actor in the teaching-learning process. As an individual and as a member of a social group, the student has to participate actively in the common goal of consolidating the sustainable development. Therefore, the use of participative teaching methodologies is preferred. In the context of distance education, as is the case of UNED, these types of methodologies can benefit greatly from the possibilities that information and communication technologies provide for the education. Some of the preferred procedures include: groups of collaborative learning, creation of mind maps, peer evaluation in the assessment framework aimed at the learning process, discussion forums, or active participation in experiences that stimulate both the acquisition of knowledge and social commitment, as in the case of service learning.

The process of evaluating results completes the model. The evaluation rubric is used as an instrument pattern, as per Table 3. Each of the four competency areas utilized performance indicators corresponding to three potential levels of achievement, since "the development of skills can be viewed in a continuum because each person can master these skills to a certain degree, and this degree of mastery should be evaluated by faculty" [79] (p. 360). In some cases, evidence of a quantitative nature is used, such as the number of factors involved in a particular identified phenomenon. In other cases, the evidence has a qualitative character, as in the case of argumentative explanations or causal relationships. 
Table 3. Rubric for the evaluation of performance of general competencies in sustainability.

\begin{tabular}{|c|c|c|c|}
\hline \multirow[t]{2}{*}{$\begin{array}{c}\text { Areas of } \\
\text { competence }\end{array}$} & \multicolumn{3}{|c|}{$\begin{array}{l}\text { INDICATORS AND PERFORMANCE LEVELS } \\
\text { (Faced with an event, the student is capable of...) }\end{array}$} \\
\hline & Level 1 & Level 2 & Level 3 \\
\hline $\begin{array}{l}\text { Systemic } \\
\text { thinking }\end{array}$ & $\begin{array}{l}\text { Enumerate the main } \\
\text { elements of the event and } \\
\text { their reciprocal } \\
\text { interrelations }\end{array}$ & $\begin{array}{l}\text { Explain the interrelations of } \\
\text { different type and level } \\
\text { among factors and elements }\end{array}$ & $\begin{array}{l}\text { Justify the "emergencies" as } \\
\text { effect of systemic dynamic }\end{array}$ \\
\hline $\begin{array}{l}\text { Critical } \\
\text { thinking }\end{array}$ & $\begin{array}{l}\text { Exhibits of strengths and } \\
\text { weakness in a reasoned } \\
\text { manner }\end{array}$ & $\begin{array}{l}\text { Explain arguments of } \\
\text { strengths and weaknesses in } \\
\text { a reasoned manner }\end{array}$ & $\begin{array}{l}\text { Issues reasoned judgments } \\
\text { from individual } \\
\text { argumentations }\end{array}$ \\
\hline $\begin{array}{l}\text { Anticipative } \\
\text { thinking }\end{array}$ & $\begin{array}{l}\text { Establishes linear } \\
\text { cause-effect relationships }\end{array}$ & $\begin{array}{l}\text { Anticipates possible } \\
\text { consequences and } \\
\text { effects of actions }\end{array}$ & $\begin{array}{l}\text { Suggests alternative ways } \\
\text { of proceeding }\end{array}$ \\
\hline $\begin{array}{l}\text { Social and } \\
\text { ethical } \\
\text { commitment }\end{array}$ & $\begin{array}{l}\text { Identifies the value of the } \\
\text { human behavior involved }\end{array}$ & $\begin{array}{l}\text { From a local perspective, } \\
\text { logically explains the social } \\
\text { and ethical implications of } \\
\text { the identified values }\end{array}$ & $\begin{array}{c}\text { From a "glocal" } \\
\text { perspective, logically } \\
\text { explains the social and } \\
\text { ethical implications of the } \\
\text { identified values }\end{array}$ \\
\hline
\end{tabular}

Currently, the model is being implemented in different courses and is yet to be evaluated. For this reason it is premature to advance conclusions which could not be supported by evidence. However, informal feedback of professors and students involved in the process has thus far been very positive. The contextualized application of the model permits the planning of training projects bearing in mind both the profiles of target students-characteristics, interests and previous studies-and the characteristics of the disciplines to be taught. In practice, the model favors quality control of the training processes by establishing concrete performance evidence, which is easy to assess in the context of university education practice. Quality control is one of the major difficulties that teachers confront in the framework of training for competencies, given the versatile and applied character of such competencies.

\section{Final Comments}

Contributing to the academic training of the key competencies that are necessary for people to actively participate in the processes of sustainable development is an inherent function of the university.

Each university satisfies this function to a different degree when it plans and implements teaching-learning processes for competencies in sustainability, which are both specialized-in the context of professional studies corresponding to some sectors of the green economy-and general, that is, those competencies in sustainability which should be acquired by all students of all degrees.

Regarding the specialized competencies, the high levels of quality and industry in Spain in some of the forefront sectors of the green economy, such as wind and solar energy, support the role of the university in the academic training required for these industries. With respect to the teaching of generic competencies in sustainability, universities act via two main strategies. The first strategy consists of 
boosting student awareness processes in relation to environmental challenges, even the more basic ones; for example, the need to optimize efficiency in the use of natural resources, encouraging classification and recycling of waste, or promoting sustainable means of transport. The second strategy, of greater importance, consists of taking on more complex training processes that allow participants to understand the interrelations between the ecological crisis and the other dimensions of sustainable development, or the deepest roots of environment-related complications and, consequently, accepting an active commitment to the change towards sustainability.

In both cases, it is about training processes that result in the acquisition on the part of the students of general competencies in sustainability, competencies that are necessary to all citizens in the different roles they must perform, as professionals, parents, neighbors, etc. There are processes whose planning requires us to seriously take into account that one of the keys of human behavior regarding the environmental problem is the world of personal meaning, beliefs and specific values of each human being [80]. Consequently, the competencies of sustainability have a strong component of values. For this reason we are not in the field of simple instruction, or training of skills, but in the field of education. This is the most genuine field in the university.

To conclude, even if it is necessary to acknowledge the long stretch ahead, it is also pertinent to confirm that universities in Spain have already made the first steps. Significant steps have been taken as environmental awareness increases in university communities and academic authorities. It is fair to affirm that in the next few years, on the occasion of the revision foreseen for the accreditation of studies for university degrees, the support of CADEP could facilitate most of the inclusion of competencies in sustainability among those considered key at the university level.

Equally, the number of university teaching centers which manage the teaching of sustainability criteria is expected to increase, not only because of economic efficiency reasons, but also for social and ecological reasons, as a response to an increasing awareness of the population towards the difficulties in achieving sustainable development, and the need to improve quality of life. Sustainable development consists of a quality of life whereby the coordinates establish the leading ideology that pinpoint the social usages and customs, whilst acting as a magnifying glass of the aspects considered of priority. This is an aspect not to be overlooked when planning training processes in sustainability, that is, to place the necessary emphasis on the change of attitudes and values, and not to neglect the building of rigorous knowledge. Even if what is truly important is not knowledge, but rather social attitudes and practices, we must bear in mind that values are built from knowledge, that in turn leads to dialogue, individual and social awareness, and argumentative communication [81] (p. 221).

All the above must not disregard the necessary training in specialized competencies in sustainability, that is, those competencies that are directly required to perform green jobs. In Spain, where there are high-quality standards in some of the leading sectors of the green economy (such as wind or solar energy), universities play a definite role. However, "moving towards a green economy will require world leaders, civil society and leading businesses to collaboratively engage in this transition. It will require a sustained effort on the part of policy makers and their constituents to rethink and redefine traditional measures of wealth, prosperity and well-being” [2] (p. 630). 


\section{Acknowledgments}

The author would like to thank the financial support from the UNED (Spain) and she also sincerely appreciates the great assistance and valuable comments from María Novo, Chairholder of the UNESCO Chair in Environmental Education and Sustainable Development.

\section{Conflicts of Interest}

The author declares no conflict of interest.

\section{References and Notes}

1. UN. Report of the United Nations Conference on Sustainable Development. Rio de Janeiro, Brazil, 20-22 June 2012. A/CONF.216/16. Available online: http:/www.uncsd2012.org/content/ documents/814UNCSD\%20REPORT\%20final\%20revs.pdf (accessed on 2 January 2014).

2. UNEP. Towards a Green Economy. Pathways to Sustainable Development and Poverty Eradication. 2011. Available online: http://www.unep.org/greeneconomy/Portals/88/documents/ ger/ger_final_dec_2011/Green\%20EconomyReport_Final_Dec2011.pdf (accessed on 2 January 2014).

3. Jänicke, M. 'Green growth': From a growing eco-industry to economic sustainability. Energy Policy 2012, 48, 13-21.

4. Barbier, E.B.; Markandya, A. A New Blueprint for a Green Economy; Routledge: Abingdon, UK, 2013.

5. Barbier, E.B. The green economy Post Rio+20. Science 2012, 338, 887-888.

6. Bina, O. The green economy and sustainable development: An uneasy balance? Environ. Plan. C: Gov. Policy 2013, 31, 1023-1047.

7. European Environment Agency. Natural resources and human well-being in a green economy. Available online: http://www.worldresourcesforum.org/files/WRF2013/Workshops/WRF_ Hoogeveen\%20WS\%2010.pdf (accessed on 16 April 2014).

8. ILO. Working towards sustainable development: Opportunities for decent work and social inclusion in a green economy, International Labour Organisation, 2012, Geneva. Available online: http://www.ilo.org/wcmsp5/groups/public/---dgreports/---dcomm/---pub1/documents/publication/ wcms_181836.pdf(accessed on 16 April 2014).

9. OECD. Declaration on Green Growth adopted at the Council Meeting at Ministerial Level on 24 June, C/MIN(2009)5/ADD1/FINAL. Available online: http://www.oecd.org/env/44077822.pdf (accessed on 16 April 2014).

10. European Commission. Taking stock of the Europe 2020 strategy for smart, sustainable and inclusive growth, Brussels, $\operatorname{COM}(2014) 130$ final. Available online: http://ec.europa.eu/ europe2020/pdf/europe2020stocktaking_en.pdf (accessed on 16 April 2014).

11. Martínez-Fernández, C.; Ranieri, A.; Sharpe, S. Green skills for a low-carbon future. In OECD/Cedefop. Greener Skills and Jobs, OECD Green Growth Studies; OECD Publishing: Paris, France, 2014. Available online: http://dx.doi.org/10.1787/9789264208704-en (accessed on 2 January 2014). 
12. European Commission. Life creating green jobs and skills, 2013. Available online: http://ec.europa.eu/environment/life/publications/lifepublications/lifefocus/documents/jobs_skills. pdf (accessed on 2 January 2014).

13. CEDEFOP. Skills for Green Jobs; European Centre for the Development of Vocational Training, Publications Office of the European Union: Luxembourg, 2010. Available online: http://www.cedefop.europa.eu/EN/Files/3057_en.pdf (accessed on 2 January 2014).

14. UNESCO. Records of General Conference. Volume 1. Resolutions. 32nd Session, Paris, 29 September to 17 October, 2003. Available online: http://unesdoc.unesco.org/images/0013/ 001331/133171e.pdf (accessed on 2 January 2014).

15. Vilela, M.; Corrigan, K. Good Practices using the Earth Charter. Education for Sustainable Development in Action. UNESCO and ECI Secretariat, 2007. Available online: http://www.earthcharterinaction.org/invent/images/uploads/Good\%20Practices.pdf (accessed on 2 January 2014).

16. Arenas Ortiz, M.; Hinojosa Pareja, E.F.; López López, $\mathrm{M}^{\mathrm{a} C}$. La Carta de la Tierra: Experiencias internacionales de innovación en educación superior. Teor. Educ. Rev. Interuniv. 2013, 25, 79-107.

17. Corcoran, P.B.; Wohlpart, A.J. Infusing the Earth Charter into Research and Curriculum: One American University's example. In Good Practices in Education for Sustainable Development Using the Earth Charter; Vilela, M., Corrigan, K., Eds; UNESCO and the Earth Charter Initiative: San José de Costa Rica, Costa Rica, 2007; pp. 110-115.

18. Clugston, R.M.; Calder, W.; Corcoran, P.B. Teaching sustainability with the Earth Charter. In Teaching Sustainability at Universities: Towards Curriculum Greening; Filho, W.L., Ed.; Peter Lang: Frankfurt, Germany, 2002; pp. 547-564.

19. Jiménez-Elizondo, A.; Creads, A. Teacher Training Course on ESD in Costa Rica. J. Educ. Sustain. Dev. 2010, 4, 227-234.

20. Clugston, R. Earth Charter Education for Sustainable Ways of Living. J. Educ. Sustain. Dev. 2010, 4, 157-166.

21. Brenes, A. Education for Sustainable Development based on the Earth Charter. Factis Pax. J. Peace Educ. Soc. Justice 2008, 2, 1-29.

22. ECI Secretariat. Green Economy and the Earth Charter. ECI Secretariat. 2011. Available online: http://www.earthcharterinaction.org/invent/images/uploads/Green_Economy_and_the_EC_-_ by_ECI_Secretariat_March\%202011.pdf (accessed on 2 January 2014).

23. Barth, M.; Godemann, J.; Rieckmann, M.; Stoltenberg, U. Developing key competencies for sustainable development in higher education. Int. J. Sustain. High. Educ. 2007, 8, 416-430.

24. De Haan, G. The development of ESD-related competencies in supportive institutional frameworks. Int. Rev. Educ. 2010, 56, 315-328.

25. Harder, M. The Development of Indicators \& Assessment Tools for CSO Values-based projects in Education for Sustainable Development (ESD); Final Report. Project ESDinds; University of Brighton: Brighton, England, 2011. Available online: http://www.brighton.ac.uk/sdecu/research/ esdinds/documents/Deliverable\%2017\%20Final\%20Report\%20FOR\%20UPLOAD.pdf (accessed on 2 January 2014). 
26. Parkin, S.; Johnston, A.; Buckland, H.; Brookes, F.; White, E. Learning and skills for sustainable development. Developing a sustainability literate society. Guidance for Higher Education Institutions. Forum for the Future/Higher Education Partnership for Sustainability: London, UK, 2004. Available online: http://www.forumforthefuture.org.uk/files/ learningandsskills.pdf (accessed on 2 January 2014).

27. Sleurs, W. Competencies for ESD (Education for Sustainable Development) teachers. A framework to integrate ESD in the curriculum of teacher training institutes, Comenius 2.1 project 118277-cp-1-2004-be-comenius-c2.1. Www.csct-project.org. Brussels, 2008. Available online: http://www.unece.org/fileadmin/DAM/env/esd/inf.meeting.docs/EGonInd/8mtg/CSCT\%20Handb ook_Extract.pdf (accessed on 2 January 2014).

28. Rieckmann, M. Key Competencies for a Sustainable Development of the World Society. Results of a Delphi Study in Europe and Latin America. GAIA 2011, 20, 48-56. doi:10.1016/j.futures.2011.09.005.

29. Rieckmann, M. Future-oriented higher education: Which key competencies should be fostered through university teaching and learning? Futures 2012, 44, 127-135.

30. Tilbury, D.; Podger, P.; Reid, A. Change in Curricula and Graduate Skills Towards Sustainability; Final Report prepared for the Department of the Australian Government Department of the Environment and Heritage and Macquarie University, 2004. Available online: http://aries.mq.edu.au/publications/other/Education/ACTS_Report.pdf (accessed on 2 January 2014).

31. UNECE. Learning for the future: Competencies in Education for Sustainable Development. United Nations Economic Commission for Europe/Steering Committee on Education for Sustainable Development, 2011. Available online: http://www.unece.org/fileadmin/DAM/env/ esd/ESD_Publications/Competences_Publication.pdf (accessed on 2 January 2014).

32. Wiek, A.; Withycombe, L.; Redman, CH.L. Key competencies in sustainability: A reference framework for academic program development. Sustain. Sci. 2011, 6, 203-218. doi:10.1007/s11625-011-0132-6.

33. Wiek, A.; Withycombe, L.; Redman, C.; Mills, S.B. Moving Forward on Competence in Sustainability Research and Problem Solving. Environ. Mag. 2011, 53, 3-12.

34. Stibbe, A., Ed. The Handbook of Sustainability Literacy: Skills for a Changing World; Green Books: Foxhole, UK, 2009.

35. Sibbel, A. Pathways towards sustainability through higher education. Int. J. Sustain. High. Educ. 2009, 10, 68-82. doi:10.1108/14676370910925262.

36. Wals, A.E.J. Sustainability in higher education in the context of the UNDESD: A review of learning and institutionalization processes. J. Clean. Prod. 2014, 62, 8-15.

37. Tilbury, D. Education for Sustainable Development. An Expert Review of Processes and Learning; Unesco: Paris, France, 2011. Available online: http://unesdoc.unesco.org/images/0019/ 001914/191442e.pdf (accessed on 2 January 2014).

38. UN. Report of the United Nations Conference on Sustainable Development; Rio de Janeiro, Brazil. 3-14 June 1992. A/CONF.151/26 (vol. III). Available online: http://www.un.org/ documents/ga/conf151/aconf15126-3 (accessed on 2 January 2014). 
39. European Commission. COPERNICUS-Guidelines for Sustainable Development in the European Higher Education Area. How to incorporate the principles of sustainable development into the Bologna Process. Available online: http://www.unece.org/fileadmin/DAM/env/esd/information/ COPERNICUS\%20Guidelines.pdf (accessed on 31 January 2014).

40. Autonomous University of Madrid, website of the ECOCAMPUS Project. Available online: http://www.uam.es/servicios/ecocampus/especifica/ (accessed on 30 January 2014).

41. Valencia University, website of the Projecte Campus Sostenible-UVEG. Available online: http://www.uv.es/uvweb/oficina-politiques-excel-lencia/ca/oficina-politiques-excel-lencia-opex/ universitat-valencia-traves-projecte-campus-sostenible-incorpora-mes-vehicles-electrics-motiusetmana-mobilitat-1285866876887/Novetat.html?id=1285891405986 (accessed on 30 January 2014).

42. Autonomous Universities of Barcelona and Girona, website of the ACES network. Available online: http://insma.udg.es/ambientalitzacio/web_alfastinas/angles/a_index.htm (accessed on 30 January 2014).

43. Website of the EDUSOST network. Available online: http://edusot.cat/view/12/27/lang.es/ (accessed on 30 January 2014).

44. UNED, website of the Unesco Chair in Environmental Education and Sustainable Development. Available online: http://www.uned.es/catedraunesco-educam/ (accessed on 30 January 2014).

45. Website of the CADEP-CRUE. Available online: http://www.crue.org/opencms/opencms/ Sostenibilidad/CADEP.html (accessed on 30 January 2014).

46. European Council. Presidency Conclusions. Lisbon European Council 23 and 24 March 2000. Available online: http://www.europarl.europa.eu/summits/lis1_en.htm (accessed on 2 January 2014).

47. European Commission. Europe 2020. A European strategy for smart, sustainable and inclusive growth. European Commission. 2010. Available online: http://ec.europa.eu/commission_20102014/president/news/documents/pdf/20100303_1_en.pdf (accessed on 2 January 2014).

48. Aznar, P.; Martínez-Agut, M.P.; Palacios, B.; Piñero, A.; U1l, A. Introducing sustainability into university curricula: An indicator and baseline survey of the views of university teachers at the University of Valencia. Environ. Educ. Res. 2011, 17, 145-166.

49. Barrón, Á.; Navarrete, A.; Ferrer-Balas, D. Sostenibilización curricular en las universidades españolas. ¿Ha llegado la hora de actuar? Rev. Eureka Sobre Enseñ. Divulg. Cienc. 2010, 7, 388-399. doi:10498/9877. Available online: http://rodin.uca.es/xmlui/bitstream/handle/10498/ 9877/16_Comision_CRUE_2010.pdf?sequence=1 (accessed on 2 January 2014).

50. Murga Menoyo, M.Á. Percepciones, valores y actitudes ante el desarrollo sostenible. Detección de necesidades educativas en estudiantes universitarios. Rev. Esp. Pedagog. 2008, 240, 327-343.

51. Gomera Martínez, A.; Villamandos de la Torrre, F.; Vaquero Abellán, M. Medición y categorización de la conciencia ambiental del alumnado universitario: Contribución de la Universidad a su fortalecimiento. Rev. Curric. Form. Profr. 2012, 16, 213-228.

52. Segalàs, J.; Ferrer-Balas, D.; Svansrom, M.; Lundqvist, U.; Mulder, K. What has to be learnt for sustainability? A comparison of bachelor engineering education competences at three European universities. Sustain. Sci. 2009, 4, 17-27.

53. Aznar Minguet, P.; Ull, A.; Piñero A.; Martinez-Agut, M.P. La sostenibilidad en la formación universitaria: Desafíos y oportunidades. Educ. XX1 2014, 17, 131-158. 
54. Azcarate, P.; Navarrete, A.; García, E. Aproximación al nivel de inclusión de la sostenibilidad en los curricula universitarios. Rev. Curric. Form. Profr. 2012, 16, 105-119.

55. Novo, M.; Murga-Menoyo, M ${ }^{\mathrm{a}} \mathrm{A}$;; Bautista-Cerro, $\mathrm{M}^{\mathrm{a} J}$. Educational advances and trends for sustainable development: A research project on educational innovation. J. Balt. Sci. Educ. 2010, 9, 302-314.

56. Murga-Menoyo, $\mathrm{M}^{\mathrm{a}} \mathrm{A}$. Potentiality of collaborative learning to train behaviours oriented towards sustainability. In Higher Education and the Challenge of Sustainability: Problems, Promises and Good Practice; Filho, W.L., Manolas, E.I., Sotirakou, M.N., Boutakis, G.A., Eds.; Enviromental Education Center of Soufli: Orestiada, Greece, 2007; pp. 167-177.

57. Novo, M.; Murga-Menoyo, MaA. Environmental Education of key People for Sustainable Development: A Case-Study. In Sustainable at Universities. Opportunities, Challenges and Trends; Filho, W.L., Ed.; Peter Lang: Frankfurt am Main, Germany, 2009; pp. 163-178.

58. Sáenz-Rico de Santiago, Mª B. Ejemplificación del Diseño Curricular por Competencias en el Contexto del Espacio Europeo de Educación Superior; Grupo Editorial Universitario: Granada, Spain, 2009. (In Spanish)

59. Bonil, J.; Calafell1, G.; Granados, J.; Junyent, M.; Tarín, R.M. Un modelo formativo para avanzar en la ambientalización curricular. Rev. Curric. Form. Profr. 2012, 16, 145-163.

60. Vilches Peña, A.; Gil Pérez, D. La educación para la sostenibildiad en la universidad. El reto de la formación del profesorado. Rev. Curric. Form. Profr. 2012, 16, 25-43.

61. Vilches, A.; Gil Pérez, D. Creating a Sustainable Future: Some Philosophical and Educational Considerations for Chemistry Teaching. Sci. Educ. 2013, 22, 1857-1872.

62. Junyent, M. The ACES Network: Greening the Curriculum of Higher Education. In Good Practices in Teacher Education Institutions; Hopkins, C., McKeown, R., Eds.; UNESCO: Paris, France, 2007; pp. 29-34.

63. Junyent, M.; Geli de Ciurana, A.M. Education for sustainability in university studies: A model for reorienting the curriculum. Br. Educ. Res. J. 2008, 34, 763-782.

64. Geli, A.M.; Leal Filho, W. Education for sustainability in university studies: Experiences from a project involving European and Latin American universities. Int. J. Sustain. High. Educ. 2006, 7, 81-93.

65. CADEP. Resolución aprobada en plenario. Jornadas del Seminario permanente de la Comisión Sectorial de la CRUE para la Calidad Ambiental, Desarrollo Sostenible y la Prevención de Riesgos (CADEP), Valencia, Spain, 8-9 marzo de 2012.

66. González, J.; Wagenaar, R. Tuning Educational Structures in Europe. Informe Final; Proyecto piloto-Fase 1Universidad de Deusto: Bilbao, Spain, 2003.

67. OECD. The Definition and Selection of Key Competencies. Executive Summary. OECD, 2005. Available online: http://www.oecd.org/pisa/35070367.pdf (accessed on 2 January 2014).

68. Murga-Menoyo, $\mathrm{M}^{\mathrm{a}} \mathrm{A}$.; Bautista-Cerro, $\mathrm{M}^{\mathrm{a} J}$.; Novo, M. Mapas conceptuales con Cmap tools en la enseñanza universitaria de la Educación Ambiental. Estudio de caso en la UNED. Rev. Enseñ. Cienc. 2010, 29, 47-60. Available online: www.raco.cat/index.php/Ensenanza/article/download/ 243822/353425 (accessed on 2 January 2014). 
69. Murga, MaA.; Novo, M.; Melendro, M.; Bautista-Cerro, Maj. Educación Ambiental mediante grupos de aprendizaje colaborativo en red. Una experiencia piloto para la construcción del EEES. Rev. Electrón. Teor. Educ. Educ. Cult. Soc. Inf. 2008, 9, 65-77. Available online: http://www.usal.es/ teoriaeducacion/rev_numero_09_01/murga.pdf (accessed on 2 January 2014).

70. Murga-Menoyo, M.A. Infotecnología e innovación docente. Los editores de mapas conceptuales: Posibilidades y límites. Rev. Esp. Pedagog. 2011, 249, 273-288.

71. Morin, E. From the concept of system to the paradigm of complexity. J. Soc. Evol. Syst. 1992, 15, 371-385.

72. Morin, E. La complexité humaine; Flammarion Publishing: Paris, France, 1994. Available online: http://unesdoc.unesco.org/images/0011/001177/117740eo.pdf (accessed on 2 January 2014).

73. Morin, E. Seven Complex Lessons in Education for the Future; UNESCO: Paris, France, 1999.

74. Morin, E. Restricted complexity, general complexity. In World-Views Science, and US: Philosophy and Complexity; Gershenson, C., Aerts, D., Edmonds, B., Eds.; World Scientific Publishing: New York, NY, USA, 2007; pp. 5-29.

75. Morin, E. On Complexity; Hampton Press: Cresskill, NJ, USA, 2008.

76. Morin, E. The reform of thought, transdisciplinarity, and the reform of the university. In Transdisciplinarity: Theory and Practice; Nicolescu, B., Ed.; Hampton Press: Cresskill, NJ, USA, 2008; pp. 23-32.

77. ECI/Earth Charter Initiative Earth Charter. ECI Secretariat. 2000. Available online: http://www.earthcharterinaction.org/invent/images/uploads/echarter_english.pdf (accessed on 2 January 2014).

78. Delors, J. Learning: The treasure within. Unesco, 1996. Available online: http://unesdoc.unesco.org/images/0010/001095/109590eo.pdf (accessed on 16 April 2014).

79. Galán, A.; Amilburu, M.G.; Muñoz, I. The effects of implementing the ESHE on the assessment of teaching competency in Spain. Rev. Catalana Públic 2012, 44, 349-370.

80. Ortega Ruiz, P.; Romero Sánchez, E. La dimensión ética de la crisis medioambiental. Propuestas pedagógicas. Teor. Educ. Rev. Interuniv. 2009, 21, 161-178.

81. García del Dujo, A.; Muñoz Rodríguez, J.M. Enfoques tradicionales y enfoques emergentes en la construcción del marco teórico de la Educación Ambiental para el Desarrollo Sostenible. Rev. Esp. Pedagog. 2013, 255, 209-226.

(C) 2014 by the authors; licensee MDPI, Basel, Switzerland. This article is an open access article distributed under the terms and conditions of the Creative Commons Attribution license (http://creativecommons.org/licenses/by/3.0/). 